\title{
Descriptions of larvae of Megadytes (Coleoptera: Dytiscidae: Dytiscinae): The hypothesis of monophyletic origin revisited
}

\author{
MARIANO C. MICHAT \\ Laboratorio de Entomología, Departamento de Biodiversidad y Biología Experimental, Facultad de Ciencias Exactas y Naturales, \\ Universidad de Buenos Aires, Av. Int. Güiraldes s/n, Ciudad Universitaria, 1428 Buenos Aires, Argentina; \\ e-mail: marianoide@bg.fcen.uba.ar
}

Key words. Coleoptera, Dytiscidae, Megadytes, larval morphology, chaetotaxy, phylogeny

\begin{abstract}
The three larval instars of Megadytes (Paramegadytes) glaucus (Brullé, 1838) and the third-instar larvae of M. (Bifurcitus) magnus Trémouilles \& Bachmann, 1980 and M. (Trifurcitus) robustus (Aubé, 1838) are described and illustrated for the first time, with particular emphasis on the morphometry and chaetotaxy. A key to the subgenera of Megadytes Sharp, 1882 is presented. In a cladistic analysis of third-instar larval characters, Megadytes is resolved as non-monophyletic; the species of Cybistrini studied, except those included in the subgenus Trifurcitus Brinck, 1945, share three synapomorphies: (i) medial projection of frontoclypeus truncate apically, with many apical setae directed forwards; (ii) lateral projections of frontoclypeus project forwards, not flattened; and (iii) median process of prementum rounded apically. The clade composed of the subgenera Megadytes s. str., Paramegadytes Trémouilles \& Bachmann, 1980 and Bifurcitus Brinck, 1945 along with Cybister lateralimarginalis (De Geer, 1774) is well supported by three synapomorphies: (i) head capsule subrectangular and (ii) distal third of mandible more strongly projected inwards, (iii) with a ring of long, hair-like setae. The two species of the subgenus Paramegadytes have bilobed lateral projections on the frontoclypeus. Megadytes (M.) marginithorax (Perty, 1830) is characterized by the very narrow notches between the medial and lateral projections of frontoclypeus. No synapomorphies were discovered to group together the two species of the subgenus Bifurcitus.
\end{abstract}

\section{INTRODUCTION}

The Neotropical genus Megadytes Sharp, 1882 consists of 21 species of large to very large diving-beetles. Megadytes is placed within the tribe Cybistrini, subfamily Dytiscinae and is presently divided into four subgenera (Nilsson, 2001). The subgenera Megadytes s. str., Trifurcitus Brinck, 1945 and Bifurcitus Brinck, 1945 include 10 , six and three species respectively and are widely distributed throughout the Neotropics (Trémouilles \& Bachmann, 1980). The fourth and more recently erected subgenus, Paramegadytes Trémouilles \& Bachmann, 1980, includes two species restricted to Southern South America (Trémouilles \& Bachmann, 1980).

As presently defined, Megadytes is morphologically very diverse, especially the larvae. Five species (only the third-instar) have been described: $M$. (P.) australis (Germain, 1854) (Cekalovic Kuschevich, 1974), M. (P.) glaucus (Brullé, 1838) (Crespo, 1982), M. (B.) giganteus (Laporte, 1835), $M(P$.$) fallax (Aubé, 1838) and M. (M.)$ marginithorax (Perty, 1830) (Ferreira Jr., 1993, 1995). Bertrand (1934) presents succinct descriptions of seven unidentified species from different parts of the Neotropical region, assigning them to Megadytes. However, since the closely related genus Cybister Curtis, 1827 is also present in the region, the assignment of some of these larvae to Megadytes is regarded as doubtful. This indicates that the larval morphology of Megadytes is poorly known. For the species mentioned above, the first two larval instars either are unknown or were treated very superficially, and the third-instar larvae are described with different degrees of detail, making comparisons dif- ficult. Thus, this contribution is the first attempt to study the larval morphology of Megadytes in a broader sense, based on a comparative approach.

The tribe Cybistrini, as a natural group, seems well supported by the study of adults (Miller, 2000, 2001). Also, a recent study of Cybistrini based on adult morphology and DNA sequence data (Miller et al., in press) supports the monophyly of Megadytes. However, the hypothesis of a monophyletic origin of this genus within the Cybistrini has not been investigated using larval morphology. The main goals of this contribution are (i) to describe and illustrate, for the first time, the first two larval instars of $M$. (P.) glaucus (third-instar larva is redescribed) and the third-instar larvae of $M$. (B.) magnus Trémouilles \& Bachmann, 1980 and $M$. (T.) robustus (Aubé, 1838), including a detailed morphometric and chaetotaxic analysis of selected larval structures, (ii) to provide a key for the identification of the subgenera of Megadytes, and (iii) to test, using a cladistic approach, the hypothesis of a monophyletic origin of Megadytes based on larval characters.

\section{MATERIAL AND METHODS}

Specimens were cleared in lactic acid, dissected and mounted on glass slides in Hoyer's medium. Observations (at magnifications up to $\times 1000$ ) and drawings were made using an Olympus CX31 compound microscope equipped with a camera lucida. Scanning and editing of the drawings was made using a computer. The material is held in the larval collection of M. C. Michat (Laboratory of Entomology, Buenos Aires University, Argentina). 


\section{Morphometric analysis}

The same terms are employed as used in previous papers dealing with larval morphology of Dytiscidae (Alarie, 1995, 1998; Alarie et al., 2002). Paired structures of each individual were considered independently. The following measures were taken. Total length (excluding urogomphi) (TL). Maximum width (MW). Head length (HL): total head length including the frontoclypeus, measured medially along the epicranial stem. Head width (HW): maximum head width. Length of frontoclypeus (FRL): from apex of nasale to posterior margin of ecdysial suture. Occipital foramen width $(\mathrm{OCW})$ : maximum width measured along dorsal margin of occipital foramen. Coronal line length (COL). Length of mandible (MN): measured from laterobasal angle to apex. Width of MN: maximum width measured at base. Length of maxillary palpifer (PPF). Length of antenna (A), maxillary (MP) and labial (LP) palpi were determined by adding the lengths of the individual segments; each segment is denoted by the corresponding letter(s) followed by a number (e.g., A1: first antennomere). A3' is used as an abbreviation for the apical lateroventral process of the third antennomere. Length of leg (L) including the longest claw (CL) was obtained by adding the lengths of the segments; each leg is denoted by the letter L followed by a number (e.g., L1: prothoracic leg). Length of trochanter includes only the proximal portion, the length of distal portion is included in the femoral length. The legs of the larvae studied are considered to be composed of six segments following Lawrence (1991). The leg segments are referred to as CO: coxa, FE: femur, PT: pretarsus, TA: tarsus, TI: tibia and TR: trochanter. Unless otherwise indicated, pro-, meso- and metathoracic legs were similar in all aspects described. Dorsal length of last abdominal segment (LAS): measured along midline from anterior to posterior margin. Length of urogomphus (U): total length from base to apex. These measurements were used to calculate several ratios, which characterize body shape.

\section{Chaetotaxic analysis}

The number and position of setae and so-called pores (campaniform sensilla) on the head capsule, head appendages, legs, last abdominal segment and urogomphi of first-instar larva of M. glaucus were determined. The term multi-branched was used to refer to setae that split into two or more branches at a certain distance from the base. A system of nomenclature for naming the primary sensilla of larvae of the subfamily Dytiscinae has not yet been presented. Recent papers have suggested that the Lancetinae is a sister subfamily of Dytiscinae, and Colymbetinae of the clade Lancetinae + Dytiscinae (Miller, 2001). For this reason, the setae and pores present in the larvae of $M$. glaucus were first compared with those of the subfamilies Colymbetinae (sensu Miller, 2001) and Lancetinae (Alarie, 1995, 1998; Alarie et al., 2002). However, the highly derived condition of Cybistrini within Dytiscinae, indicated by the high number of additional setae in first-instar larvae, makes the establishment of homologies very difficult. For this reason, it was not possible to establish homologies for particular sensilla and therefore no particular system of nomenclature was adopted. Setae located at the apex of maxillary and labial palpi were extremely difficult to distinguish due to their position and small size. Accordingly, they are not well represented.

\section{Cladistic analysis}

To test whether the genus Megadytes is monophyletic, thirdinstar larvae of the species described here and of six other species included in the genera Cybister, Megadytes and Onychohydrus Schaum, 1847, were coded for parsimony analysis. Larvae of another tribe of Dytiscinae (Hydaticus tuyuensis
Trémouilles, 1996, Hydaticini) and of another dytiscid subfamily [Lancetes marginatus (Steinheil, 1869), Lancetinae], were included as outgroups. The data matrix was analyzed using the program TNT (Goloboff et al., 2003). The small size of the matrix allowed for the implementation of an exact solution algorithm (implicit enumeration). Branch support was calculated by jackknifing ( $\mathrm{P}=36,200$ replicates).

\section{RESULTS}

\section{Descriptions of larvae of Megadytes Sharp, 1882}

The description of each instar at the genus level was based on the species available. Thus, the descriptions of first- and second-instar larvae of the genus Megadytes were based on the study of the larvae of $M$. glaucus, and that of third-instar larva on the study of $M$. glaucus, $M$. magnus and M. robustus. As a consequence, the generic description provided here is likely to be changed when more species are studied. On the other hand, in the description of each species, only characters that differ from the generic description are included.

Diagnosis. Anterior margin of FR deeply sinuate. Egg bursters present in first-instar larva. A1 subdivided into two parts, A2 and A3 subdivided into three parts. Premaxillary lobes strongly developed, projected forwards. Stipes elongate, slender, subcylindrical; PPF elongate, palpomere-like; MP1 and MP3 subdivided into three parts, MP2 subdivided into two parts; galea absent. Median process of prementum single, finger-like, glabrous; LP1 and LP2 subdivided into two parts. Two ventral sclerites present on prothorax. Patch of dense, slender spinulae present on basal third of proTA. Abdominal tergites I to VI reduced; LAS elongate, not sclerotized around the anus. Urogomphus minute. Parietal without spine-like setae; rows of natatory setae on anteroventral margin of TR, FE and proTI, and on posterodorsal margin of FE, TI and TA; anteroventral surface of TI and meso- and metaTA with a row of apically rounded spine-like setae; lateral margins of abdominal segments VII and VIII with a row of natatory setae. This diagnosis is based on the larvae available for this study. However, as the larval morphology of the Cybistrini is poorly known, many of the characters mentioned above may actually be diagnostic at the tribe level (see discussion).

\section{Instar I}

Colour. Head capsule pale yellow except for brown maculae near egg bursters and posterodorsal to stemmata. Head appendages pale yellow except for fourth antennomere and apices of third antennomere, third maxillary palpomere and mandible brown. Thoracic tergites pale yellow, meso- and metatergite each with four brown maculae on anterior and lateral margins. Abdominal tergites pale yellow, each with four brown maculae on anterior margin. Membranous parts white. Legs white to pale yellow. Urogomphus brown.

Body (Fig. 1). Elongate, subcylindrical. Measurements and ratios that characterize the body shape are shown in Table 1. 


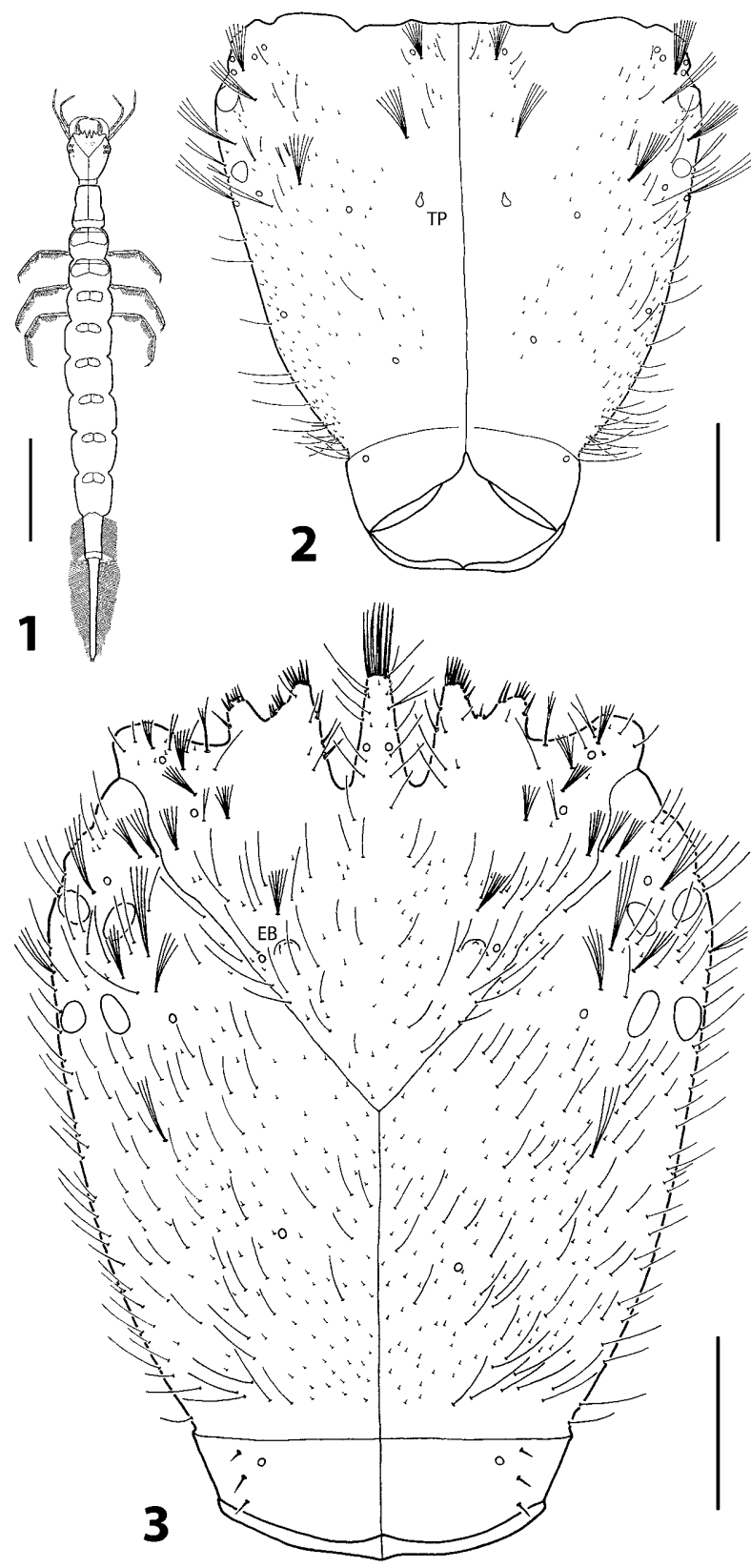

Figs 1-3. Megadytes glaucus, first-instar larva. 1 - habitus, dorsal aspect; 2-3 - cephalic capsule, ventral and dorsal aspects, respectively. EB: egg burster; TP: tentorial pit. Scale bars $=5 \mathrm{~mm}(1)$ and $0.5 \mathrm{~mm}(2-3)$.

Head. Head capsule (Figs 2-3). Flattened, subtriangular, longer than broad; maximum width at stemmata, constricted at level of occipital region; occipital suture and ecdysial line well marked; occipital foramen deeply emarginate ventrally; posterior tentorial pits visible ventrally; spinulae absent except for a band anterior to occipital suture. FR subtriangular, anterior margin deeply sinuate, with three projections, medial projection narrow, well developed, truncate apically; lateral projections prominent, bilobed; anterolateral lobes rounded, not projecting beyond anterior margin; with 1 rounded egg burster on each lateral. Four stemmata on upper side of head and two on underside, arranged in two vertical

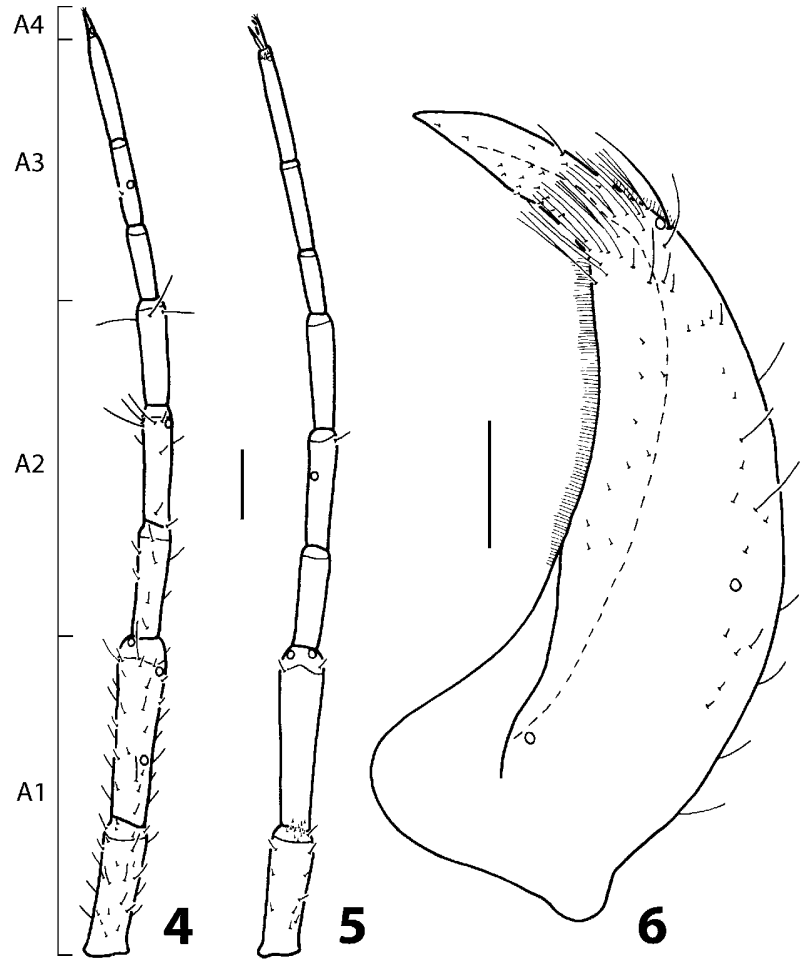

Figs 4-6. Megadytes glaucus, first-instar larva. 4-5 antenna, dorsal and ventral aspects, respectively; 6 - mandible, dorsal aspect. Scale bars $=0.2 \mathrm{~mm}$.

series. Antenna (Figs 4-5). Elongate, slender, longer than $\mathrm{HW}$, composed of four antennomeres, A2 the longest, A1 slightly shorter than A2, A3 somewhat shorter than A1; A1 subdivided into two parts, distal part somewhat longer than basal part; A2 subdivided into three subequal parts; A3 subdivided into three parts, distal part the longest, basal part the shortest; A3 with a ventroapical spinula; apical lateroventral process of A3 elongate; A4 the shortest, with a small, lateroventral process on distal third. Mandible (Fig. 6). Strong, falciform, wide at base, sharp apically, distal third straight, more strongly projected inwards; mandibular channel present. Maxilla (Figs 7-8). Premaxillary lobes strongly developed, projected forwards; cardo well developed, subovate; stipes elongate, slender, subcylindrical; PPF elongate, palpomere-like; MP elongate, slender, composed of three palpomeres, MP1 the longest, MP3 slightly shorter than MP1, MP2 the shortest; MP1 subdivided into three subequal parts; MP2 subdivided into two parts, distal part somewhat longer than basal part; MP3 subdivided into three parts, distal part the longest, basal part the shortest; galea absent. Labium (Figs 9-10). Prementum broader than long, not sclerotized along a medial, sagittal, ventral band; anterior margin broadly and deeply emarginate medially, anterodorsal margin projecting forwards in a single, finger-like, median process; LP short, composed of two palpomeres, LP1 somewhat longer than LP2; LP1 subdivided into two subequal parts; LP2 subdivided into two parts, distal part about twice as long as basal part. 
TABLE 1. Measurements and ratios for the larvae of species of Megadytes. 1: length, w: width.

\begin{tabular}{|c|c|c|c|c|c|}
\hline Measure & M. glaucus (Instar I) & M. glaucus (Instar II) & M. glaucus (Instar III) & M. magnus (Instar III) & M. robustus (Instar III) \\
\hline $\mathrm{TL}(\mathrm{mm})$ & $20.00-29.00$ & $30.00-38.00$ & $43.00-46.00$ & 89.00 & 90.00 \\
\hline MW (mm) & $1.50-2.90$ & $2.10-3.50$ & $4.00-4.50$ & 12.00 & 10.50 \\
\hline $\mathrm{HL}(\mathrm{mm})$ & $2.65-2.85$ & $4.08-4.19$ & $6.22-6.47$ & 8.64 & 7.61 \\
\hline HW (mm) & $2.01-2.12$ & $3.08-3.27$ & $5.21-5.43$ & 7.74 & 7.43 \\
\hline FRL (mm) & $1.35-1.48$ & $1.90-1.98$ & $2.63-2.67$ & 3.35 & 3.63 \\
\hline $\mathrm{OCW}(\mathrm{mm})$ & $0.82-1.04$ & $1.51-1.74$ & $2.93-3.08$ & 4.71 & 3.17 \\
\hline HL/HW & $1.32-1.35$ & $1.27-1.36$ & $1.19-1.20$ & 1.12 & 1.03 \\
\hline HW/OCW & $1.99-2.45$ & $1.89-2.08$ & $1.77-1.78$ & 1.64 & 2.34 \\
\hline $\mathrm{COL} / \mathrm{HL}$ & $0.46-0.50$ & $0.53-0.54$ & $0.58-0.59$ & 0.61 & 0.52 \\
\hline FRL/HL & $0.50-0.54$ & $0.46-0.47$ & $0.41-0.42$ & 0.39 & 0.48 \\
\hline A/HW & $1.28-1.39$ & $1.02-1.12$ & $0.84-0.90$ & 0.86 & 0.95 \\
\hline $\mathrm{A} 3 / \mathrm{A} 1$ & $0.82-0.89$ & $0.69-0.72$ & $0.55-0.56$ & $0.40-0.41$ & $0.34-0.35$ \\
\hline $\mathrm{A} 4 / \mathrm{A} 3$ & $0.10-0.12$ & $0.07-0.09$ & $0.06-0.07$ & 0.06 & 0.07 \\
\hline A3'/A4 & $0.71-0.94$ & $0.80-0.83$ & 0.83 & $0.86-0.93$ & 0.88 \\
\hline $\mathrm{MN}(1 / \mathrm{w})$ & $2.72-3.40$ & $3.04-3.20$ & $2.90-3.12$ & $2.72-2.77$ & $3.93-3.94$ \\
\hline $\mathrm{MN}(\mathrm{l}) / \mathrm{HL}$ & $0.46-0.48$ & $0.44-0.49$ & $0.51-0.53$ & 0.56 & $0.70-0.71$ \\
\hline PPF/MP1 & $0.30-0.35$ & $0.34-0.38$ & $0.40-0.42$ & 0.47 & 0.38 \\
\hline $\mathrm{A} / \mathrm{MP}$ & $1.31-1.36$ & $1.33-1.38$ & $1.38-1.47$ & $1.38-1.40$ & 1.67 \\
\hline MP3/MP2 & $1.57-1.71$ & $1.38-1.47$ & $1.23-1.30$ & $0.96-0.97$ & $0.66-0.67$ \\
\hline MP/LP & $2.39-2.56$ & $2.35-2.48$ & $2.03-2.19$ & $1.87-1.90$ & $1.72-1.73$ \\
\hline LP2/LP1 & $0.80-0.95$ & $0.83-1.00$ & $0.68-0.73$ & 0.43 & 0.32 \\
\hline $\mathrm{L} 3(\mathrm{~mm})$ & $5.97-6.53$ & $8.37-9.24$ & $12.21-13.03$ & $19.58-19.82$ & 19.02 \\
\hline $\mathrm{L} 3 / \mathrm{L} 1$ & $1.21-1.26$ & $1.22-1.27$ & $1.21-1.29$ & $1.34-1.36$ & $1.30-1.33$ \\
\hline $\mathrm{L} 3 / \mathrm{L} 2$ & $1.10-1.14$ & $1.11-1.13$ & $1.11-1.15$ & $1.14-1.16$ & $1.15-1.16$ \\
\hline L3/HW & $2.89-3.14$ & $2.66-2.82$ & $2.32-2.46$ & $2.53-2.56$ & 2.56 \\
\hline $\mathrm{L} 3(\mathrm{CO} / \mathrm{FE})$ & $0.97-1.02$ & $0.96-1.01$ & $0.99-1.04$ & 0.99 & 1.01 \\
\hline L3 (TI/FE) & $0.70-0.73$ & $0.67-0.70$ & $0.64-0.68$ & $0.70-0.71$ & 0.65 \\
\hline L3 (TA/FE) & $0.74-0.81$ & $0.65-0.68$ & $0.53-0.58$ & $0.62-0.63$ & 0.54 \\
\hline L3 (CL/TA) & $0.40-0.44$ & $0.34-0.36$ & $0.31-0.34$ & $0.22-0.23$ & 0.27 \\
\hline LAS (mm) & $4.49-4.77$ & $6.08-6.84$ & $9.25-9.78$ & 13.24 & 17.07 \\
\hline LAS/HW & $2.23-2.30$ & $1.98-2.09$ & $1.74-1.86$ & 1.71 & 2.30 \\
\hline $\mathrm{U}(\mathrm{mm})$ & $0.02-0.03$ & $0.03-0.04$ & $0.05-0.06$ & $0.09-0.10$ & $0.10-0.11$ \\
\hline
\end{tabular}

Thorax. Terga convex, pronotum somewhat shorter than meso- and metanotum combined, meso- and metanotum subequal; protergite subrectangular, margins rounded, much more developed than meso- and metatergite; meso- and metatergite transverse, with an anterotransverse carina; sagittal line well marked; thoracic venter membranous except for two anterior sclerites on prothorax; spiracles absent. Legs (Figs 11-12). Long, 6-segmented, L1 the shortest, L3 the longest; CO robust, elongate, TR subdivided into 2 parts, FE, TI and TA slender, subcylindrical, PT with 2 long, slender, slightly curved claws, anterior claw slightly longer than posterior claw on L1 and L2, posterior claw slightly longer than anterior claw on L3; proTA with a row of well-developed, ventral spinulae; spinulae on basal third of proTA small, very slender, forming a dense patch.

Abdomen. 8-segmented, segments I-VI membranous except for a small anterodorsal sclerite and a minute sclerite on each lateral; dorsal sclerites I-VI similar, subrectangular, without an anterotransverse carina, sagittal line well marked, posterior half covered with short spinulae; segment VII narrow, sclerotized dorsally and laterally, membranous ventrally, without an anterotransverse carina, sclerite covered with short spinulae; spiracles absent on segments I-VII; LAS (Figs 13-14) the longest and narrowest, completely sclerotized except ventrodistally around the anus, without an anterotransverse carina, covered with short spinulae except the distal third; siphon reduced. Urogomphus (Fig. 15). Minute, 1-segmented.

Chaetotaxy (Figs 2-15). Cephalic capsule with numerous setae, mostly minute or elongate, hair-like, and several multi-branched; parietal without spine-like setae. Frontoclypeus and parietal each with four pores on each side. Frontoclypeus with 55-64 long, slender, spine-like setae on anterior margin, arranged mostly on the apices of the projections, setae on medial projection longer than the others. A1 and A2 with about 81 and 18 hair-like setae 


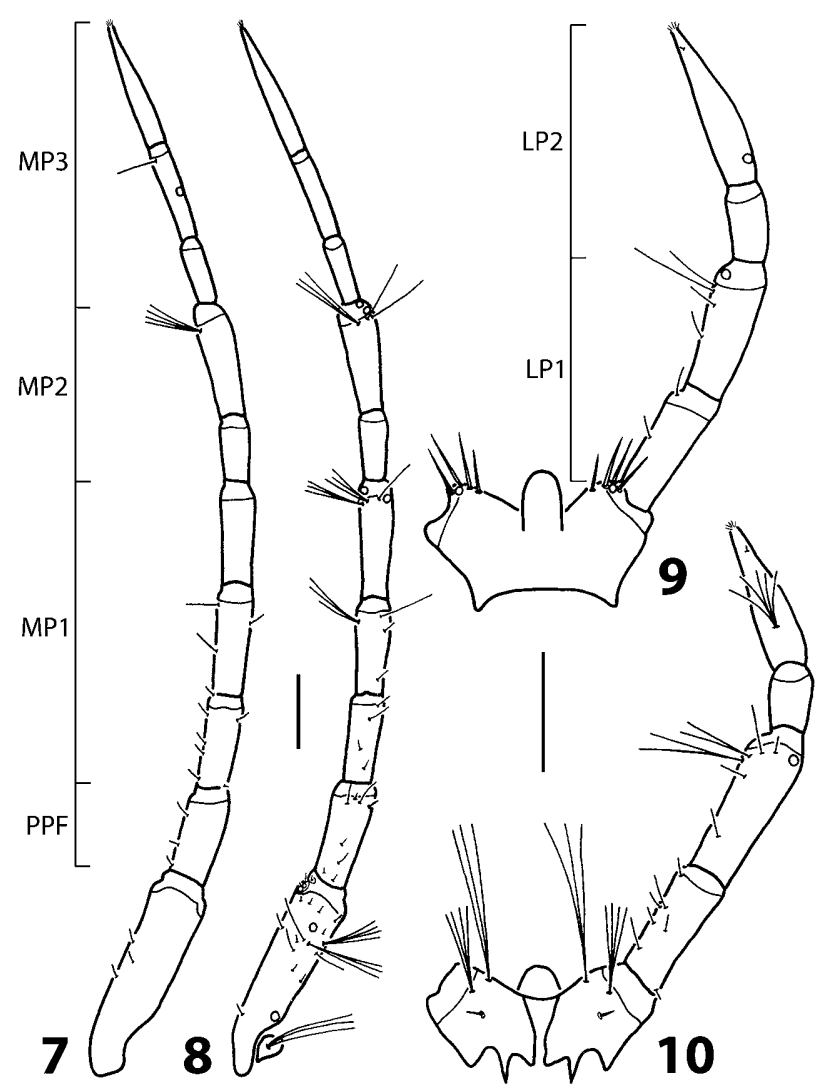

Figs 7-10. Megadytes glaucus, first-instar larva. 7-8 - maxilla, dorsal and ventral aspects, respectively; 9-10 - labium, dorsal and ventral aspects, respectively. Scale bars $=0.2 \mathrm{~mm}$.

respectively, mostly on dorsal surface; A3 with three minute setae, one medial and two distal; A1, A2, A3 and A4 with five, two, two and one pores, respectively. MN with three pores and numerous setae, mostly minute or elongate, hair-like, and a few multi-branched forming a dense ring on distal third. Stipes, PPF and MP1 with about 20, 11 and 20 hair-like setae, respectively, inserted on lateral and ventral surfaces (three setae on the stipes and three on MP1 multi-branched); MP2 with four apical setae, two of them multi-branched; MP3 with one medial, hair-like seta. Stipes, MP1, MP2 and MP3 with four, two, two and one pores, respectively. Prementum with one pore and four spine-like setae on each side of dorsal surface, and three setae (one spine-like and two multibranched) on each side of ventral surface. LP1 with two pores and about 16-18 hair-like setae on internal and ventral surfaces, two of the apical setae multi-branched; LP2 with one pore and three setae (two minute and one multibranched). Thoracic tergites with numerous hair-like setae (few multi-branched) on the whole surface. Leg segments with numerous setae, one on dorsodistal surface of each of FE, TI and TA frequently multi-branched; $\mathrm{CO}$ with one pore on anterior surface and 7-12 on posterior surface; TR with five pores on anterior surface and two on posterior surface; FE with one pore on anterior surface and one on posterior surface; TI with one pore on posterior surface; TA with four pores on anterior surface and two on posterior surface; rows of natatory setae on anteroventral margin of TR, FE and proTI, and on posterodorsal margin of FE, TI and TA (posterodorsal row of metaFE only on distal two-thirds); anteroventral surface of TI and meso- and metaTA with a row of spine-like setae rounded apically. Abdominal sclerites I-VI with several hair-like setae on posterior half; abdominal sclerite VII with numerous hair-like setae on the whole surface and a row of natatory setae on lateral margin. LAS with numerous hair-like setae and 6-10 dorsal pores; lateral margin of LAS with a row of natatory setae. U with seven setae and one pore.

\section{Instar II}

As first-instar larva except for the following features. Colour. Head capsule pale yellow to yellow with numerous small, dark brown maculae arranged in two areas: centrally on the frontoclypeus, and all over the parietals except the anterior third. Head appendages pale yellow except for fourth antennomere and apices of third antennomere, third maxillary palpomere, second labial palpomere and mandible dark brown. Thoracic tergites pale yellow to yellow, with one longitudinal, brown band on each side of midline, and numerous dark brown maculae all over the surface. Abdominal tergites I to VI

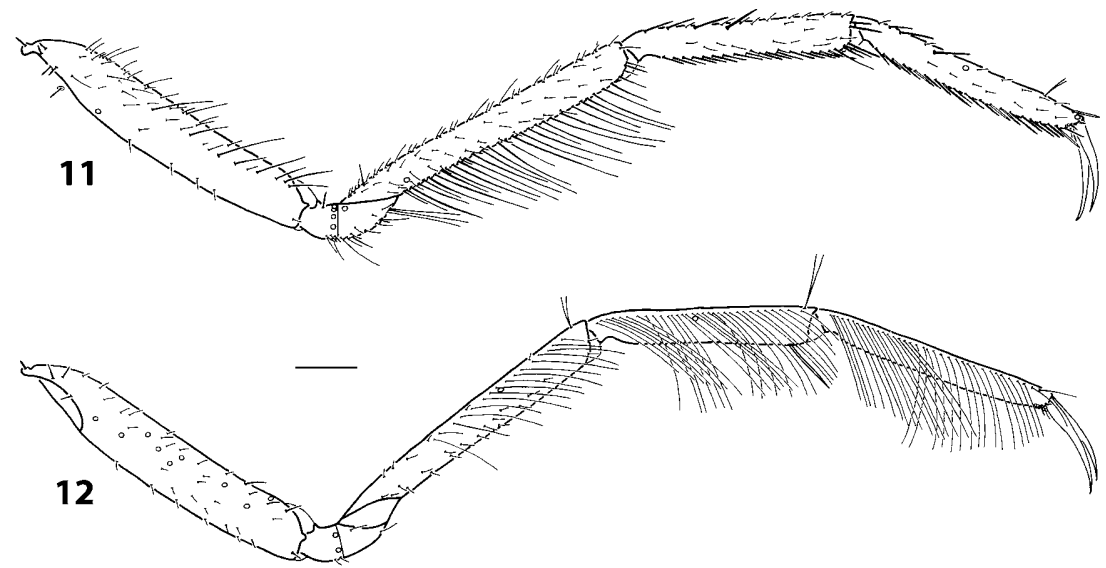

Figs 11-12. Megadytes glaucus, first-instar larva, metathoracic leg, anterior and posterior aspects, respectively. Scale bar $=0.3$ $\mathrm{mm}$. 


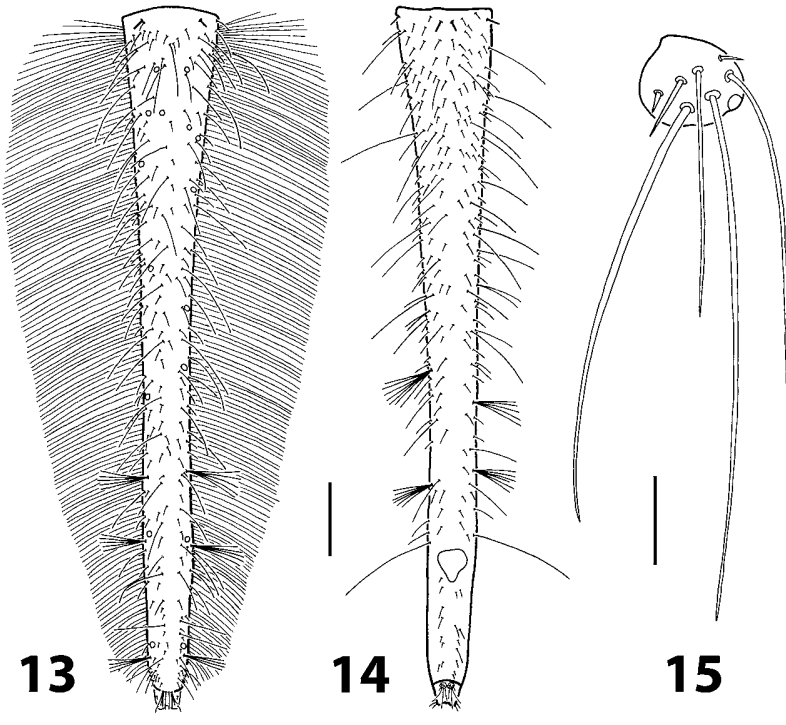

Figs 13-15. Megadytes glaucus, first-instar larva. 13-14 abdominal segment VIII, dorsal and ventral aspects, respectively; 15 - urogomphus, dorsal aspect. Scale bars $=0.5 \mathrm{~mm}$ (13-14) and $0.03 \mathrm{~mm}(15)$.

variegated, with pale yellow and brown longitudinal bands; tergite VII pale yellow to light brown except for one lighter, longitudinal, dorsal band; sclerite VIII evenly pale yellow to light brown. Membranous parts evenly white ventrally, grey with longitudinal white bands dorsally. Legs pale yellow to light brown. Body. Measurements and ratios that characterize the body shape are shown in Table 1. Head capsule. Spinulae absent. Antenna. Slightly longer than HW; A1 and A2 subequal. Labium. LP2 subdivided into two subequal parts. Abdomen. Sclerites I-VIII without spinulae; sclerite I with an anterotransverse carina. Chaetotaxy. FR with 136-159 slender, spine-like setae on anterior margin. Posterodorsal row of natatory setae on metaFE all along the segment.

\section{Instar III}

As second-instar larva except for the following features. Colour. Head capsule pale yellow to reddish brown with numerous small, dark reddish to dark brown maculae arranged in two areas: on the frontoclypeus (only centrally or covering the whole surface except the anterolateral corners), and all over the parietals except the anterior third. Head appendages pale yellow to brown except for mandible reddish brown to dark brown, fourth antennomere and apex of third antennomere brown to dark brown, and third maxillary palpomere and second labial palpomere light brown to dark brown. Thoracic tergites pale yellow to reddish brown, with one longitudinal, dark brown to brown band on each side of midline, and several to numerous dark brown maculae all over the surface. Abdominal tergites I to VI variegated, with pale yellow and brown to dark brown longitudinal bands; tergite VII light brown except for one lighter, longitudinal, dorsal band; sclerite VIII evenly pale yellow to light brown. Membranous parts either white ventrally and grey with longitudinal white bands dorsally, or white with light brown, longitudinal bands. Legs either evenly pale yellow to light brown, evenly brown except for coxa reddish brown, or evenly light brown with coxa bearing brown maculae. Urogomphus reddish brown to brown. Head capsule. Subquadrate, somewhat longer than broad or subtriangular, about as long as broad. Medial projection of FR either truncate apically, with numerous apical setae, or sharp apically, almost glabrous; lateral projections broad, flattened or prominent (in this case they can be entire or bilobed). Antenna. Somewhat shorter than HW; A1 the longest, A2 somewhat shorter than A1. Mandible. Strong, with distal third straight, more strongly projected inwards, or long, slender, evenly curved. Maxilla. MP2 the shortest, MP3 the shortest, or MP2 and MP3 subequal; relative length of parts composing MP2 and MP3 variable. Labium. Median process of prementum either rounded apically or slightly bilobed apically; LP1 longer than LP2; relative length of parts composing LP1
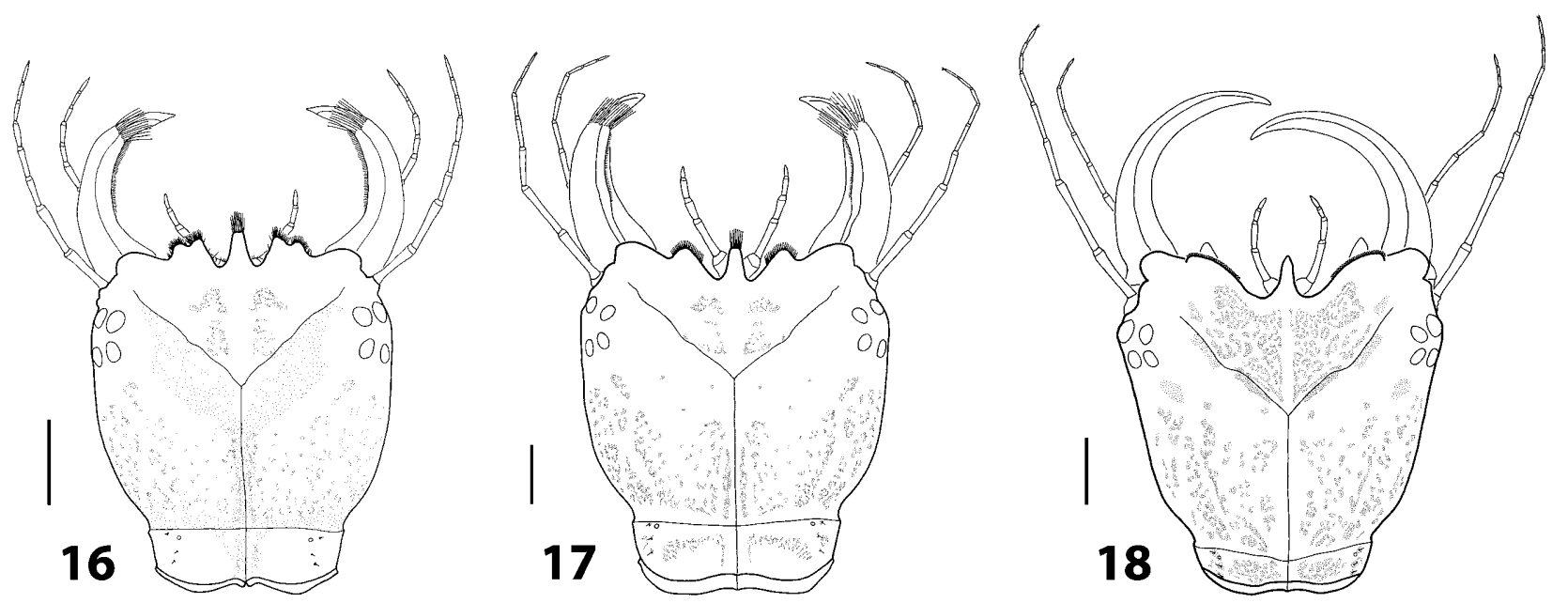

Figs 16-18. Head of third-instar larvae of species of Megadytes, dorsal aspect. 16 - M. glaucus; 17 - M. magnus; 18 - M. robustus. Setation has been omitted to emphasize colour pattern. Scale bars $=1.5 \mathrm{~mm}$. 
and LP2 variable. Thorax. Meso- and metatergite covering the whole segment dorsally; spiracles present on mesothorax. Abdomen. Segment VII either membranous or sclerotized ventrally; sclerite VII either without or with an anterotransverse carina; spiracles present on segments I-VII. Chaetotaxy. FR with about 115-216 setae on anterior margin, which are either short, stout, rounded apically or slender, spine-like. Mandible with or without a ring of multi-branched setae on distal third.

\section{Key to subgenera of Megadytes}

The following key is based on the study of the species of Megadytes listed in Table 2.

1 Medial projection of frontoclypeus sharp apically, almost glabrous (Fig. 18). Mandible evenly curved, without ring of setae on distal third (Fig. 18)........ sg. Trifurcitus Brinck

- Medial projection of frontoclypeus truncate apically, with numerous apical setae (Figs 16-17). Mandible with distal third more strongly projected inwards, bearing a ring of long setae (Figs 16-17) . . . . . . . . . . . . . . . . . . 2

2 Notches between medial and lateral projections of frontoclypeus very narrow (Fig. 8 in Ferreira Jr., 1995). . . . . . . . ............................ sg. Megadytes Sharp

- Notches between medial and lateral projections of frontoclypeus wide (Figs 16-17) . . . . . . . . . . . . . . 3

3 Lateral projections of frontoclypeus entire (Fig. 17). ....... ........................... Bifurcitus Brinck

- Lateral projections of frontoclypeus bilobed (Fig. 16). .... . .......... sg. Paramegadytes Trémouilles \& Bachmann

\section{Megadytes (Paramegadytes) glaucus (Brullé, 1838)}

Source of material. Six specimens of instar I, three of instar II and three of instar III were used for the descriptions. Larvae were collected in association with adults at the following locality: La Escondida, Bragado, Buenos Aires Province, Argentina, January 2002 and March 2005, large semipermanent pond with abundant aquatic vegetation. Megadytes glaucus is the only species of the genus present in the area where the larvae were collected.

Diagnosis. Larvae of $M$. glaucus are characterized by the following combination of characters: medial projection of FR truncate apically, with numerous apical setae; lateral projections prominent, bilobed; mandible with

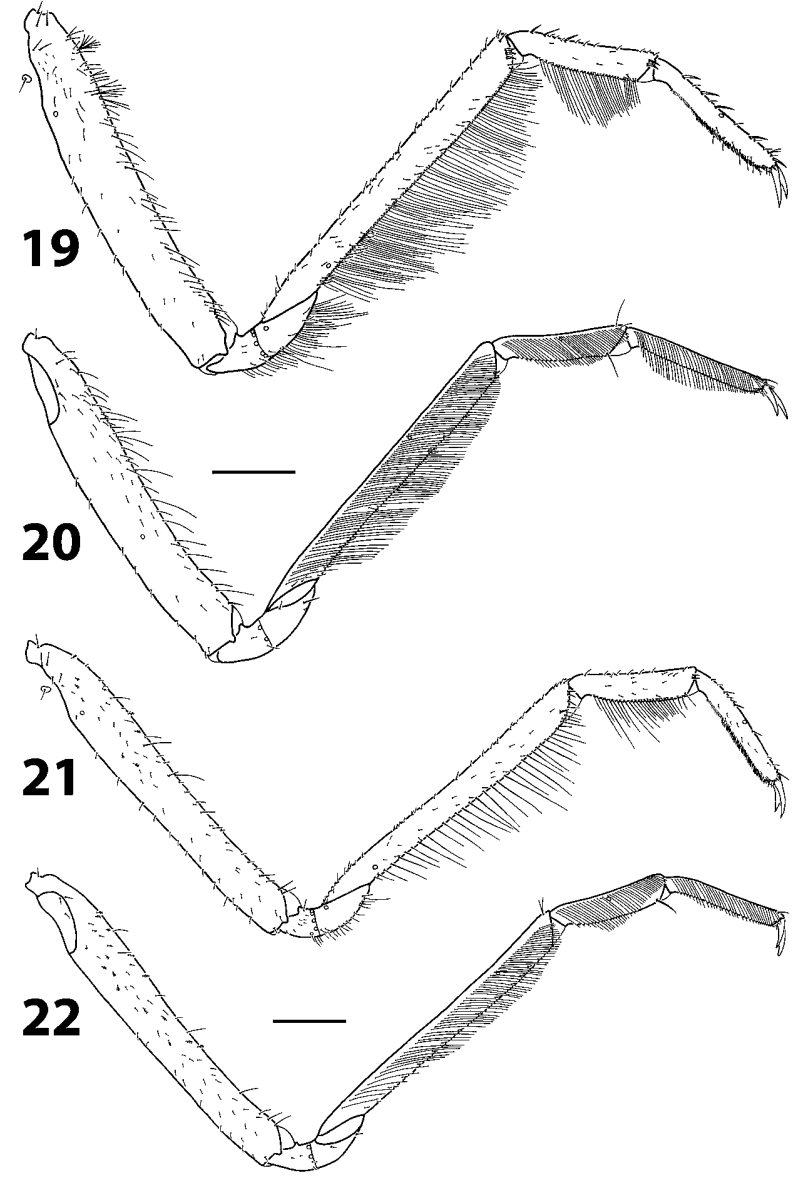

Figs 19-22. Prothoracic leg of third-instar larvae of species of Megadytes. 19-20 - M. magnus, anterior and posterior aspects, respectively; 21-22 - M. robustus, anterior and posterior aspects, respectively. Scale bars $=1 \mathrm{~mm}$.

distal third more strongly projected inwards, bearing a ring of multi-branched setae; MP2 the shortest; median process of prementum rounded apically; abdominal segment VII membranous ventrally.

Instars I and II. See under generic description.

TABLE 2. Taxa of Dytiscinae and Lancetinae coded for phylogenetic analysis.

\begin{tabular}{ccc}
\hline & \multicolumn{1}{c}{ Taxa } & Source \\
\hline DYTISCINAE & & \\
Cybistrini & Cybister lateralimarginalis & Fiori (1949); De Marzo (1979) \\
& Megadytes $($ B.) giganteus & Ferreira-Jr. (1993) \\
& Megadytes $($ B.) magnus & This paper \\
& Megadytes $(M$.$) marginithorax$ & Ferreira Jr. (1995) \\
& Megadytes $(P$.$) australis$ & M.C. Michat collection \\
& Megadytes $(T$.$) fallax$ & This paper \\
& Megadytes $(T$.$) robustus$ & M.C. Michat collection \\
Onychohydrus scutellaris & This paper \\
Hydaticini & Hydaticus tuyuensis & Watts (1964) \\
Lancetini & & Michat \& Torres (2006) \\
\hline
\end{tabular}




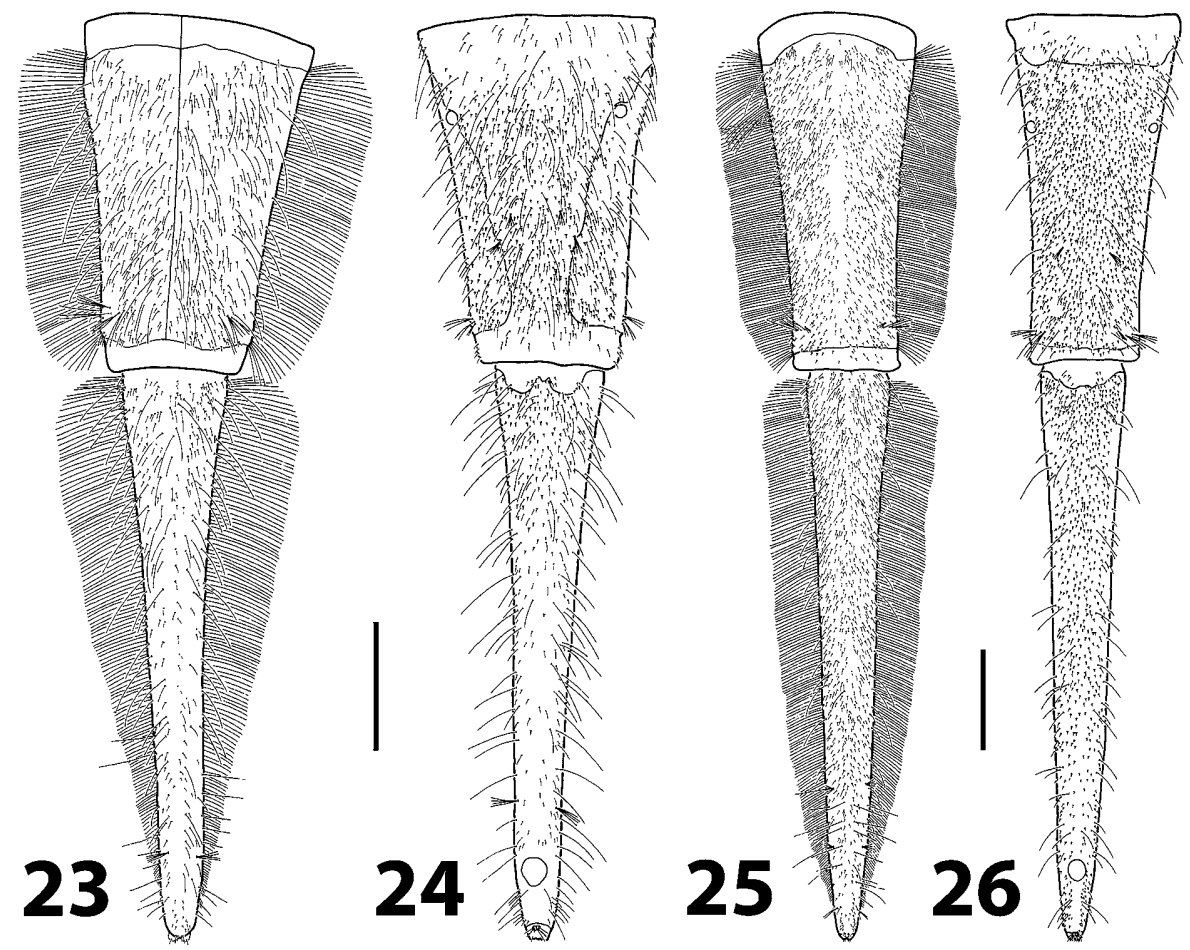

Figs 23-26. Abdominal segments VII-VIII of third-instar larvae of species of Megadytes. 23-24 - M. magnus, dorsal and ventral aspects, respectively; 25-26-M. robustus, dorsal and ventral aspects, respectively. Scale bars $=3 \mathrm{~mm}$.

Instar III. Colour. Head capsule pale yellow to yellow with numerous small, dark brown maculae arranged in two areas: centrally on the frontoclypeus, and all over the parietals except the anterior third. Head appendages pale yellow except for fourth antennomere and apices of third antennomere, third maxillary palpomere, second labial palpomere and mandible dark brown. Thoracic tergites pale yellow to yellow, with one longitudinal, brown band on each side of midline, and numerous dark brown maculae all over the surface. Abdominal tergites I to VI variegated, with pale yellow and brown longitudinal bands; tergite VII pale yellow to light brown except for one lighter, longitudinal, dorsal band; sclerite VIII evenly pale yellow to light brown. Membranous parts evenly white ventrally, grey with longitudinal white bands dorsally. Legs pale yellow to light brown. Body. Measurements and ratios that characterize the body shape are shown in Table 1. Head capsule (Fig. 16). Subquadrate, somewhat longer than broad; medial projection of FR truncate apically, with numerous apical setae; lateral projections prominent, bilobed. Mandible. Strong, with distal third straight, more strongly projected inwards. Maxilla. MP1 longer than MP3, MP2 the shortest. Labium. Median process of prementum rounded apically. Abdomen. Segment VII membranous ventrally; sclerite VII without an anterotransverse carina. Chaetotaxy. FR with 206-216 slender, spine-like setae on anterior margin; mandible with a ring of multi-branched setae on distal third.

\section{Megadytes (Bifurcitus) magnus Trémouilles \& Bachmann, 1980}

Source of material. One specimen of instar III was used for the description. It was collected at the following locality: Laguna Yema, Formosa Province, Argentina, January 1998. Megadytes magnus is the only species of the subgenus Bifurcitus present in the area where the larva was collected. The possibility that the specimen may belong to Cybister puncticollis (Brullé, 1838) is discarded based on its very large size.

Diagnosis. Larvae of $M$. magnus are characterized by the following combination of characters: medial projection of FR truncate apically, with numerous apical setae; lateral projections prominent, entire; mandible with distal third more strongly projected inwards, bearing a ring of multi-branched setae; MP2 and MP3 subequal; median process of prementum rounded apically; abdominal segment VII membranous ventrally.

Instars I and II. No specimens were available for study.

Instar III. Colour. Head capsule reddish with numerous small, dark reddish maculae arranged in two areas: centrally on the frontoclypeus, and all over the parietals except the anterior third. Head appendages light brown except for fourth antennomere and apex of third antennomere brown. Thoracic tergites reddish brown, with one longitudinal, dark brown band on each side of midline, and several dark brown maculae all over the surface. Abdominal tergites I to VI variegated, with pale yellow and dark brown longitudinal bands; tergite VII light brown except for one lighter, longitudinal, dorsal band; sclerite VIII evenly light brown. Membranous parts 
TABLE 3. Data matrix of 32 larval characters of 11 terminal taxa of Dytiscinae and Lancetinae. Missing data coded "?".

\begin{tabular}{lcccccccccc}
\hline \multirow{2}{*}{ Taxa } & \multicolumn{10}{c}{ Characters } \\
\cline { 2 - 9 } & $00-03$ & $04-07$ & $08-11$ & $12-15$ & $16-19$ & $20-23$ & $24-27$ & $28-31$ \\
\hline Lancetes marginatus & 0000 & 3000 & 0010 & 0000 & 0000 & 0002 & 0000 & 1000 \\
Hydaticus tuyuensis & 1000 & 3000 & 0011 & 0001 & 0000 & 0301 & 1110 & 1100 \\
Cybister lateralimarginalis & 0122 & 0111 & 1121 & 1111 & 1111 & $? 110$ & $? 111$ & 0111 \\
Megadytes (B.) giganteus & 0122 & 0111 & 1121 & 1111 & 1111 & 1110 & 2111 & 1111 \\
Megadytes (B.) magnus & 0122 & 0111 & 1121 & 1111 & 1111 & 1110 & 2111 & 0111 \\
Megadytes (M.) marginithorax & 0122 & 0211 & 1121 & 1111 & 1111 & 1110 & 2111 & 0111 \\
Megadytes (P.) australis & 0122 & 1111 & 1121 & 1111 & 1111 & 1110 & 2111 & 0111 \\
Megadytes (P.) glaucus & 0122 & 1111 & 1121 & 1111 & 1111 & 1110 & 2111 & 0111 \\
Megadytes (T.) fallax & 1111 & 0111 & 1121 & 0011 & 1111 & 1210 & 2111 & 0111 \\
Megadytes (T.) robustus & 1111 & 0101 & 1121 & 0011 & 1111 & 1210 & 2111 & 1111 \\
Onychohydrus scutellaris & $? 122$ & $211 ?$ & $? 121$ & $00 ? 1$ & 1111 & $? 11 ?$ & $? ? ? ?$ & $? 111$ \\
\hline
\end{tabular}

evenly white ventrally, grey with longitudinal white bands dorsally. Legs brown except for coxa reddish brown. Urogomphus reddish brown. Body. Measurements and ratios that characterize the body shape are shown in Table 1. Head capsule (Fig. 17). Subquadrate, somewhat longer than broad; medial projection of FR truncate apically, with numerous apical setae; lateral projections prominent, entire. Mandible. Strong, with distal third straight, more strongly projected inwards. Maxilla. MP2 and MP3 subequal; MP2 subdivided into two parts, basal part slightly longer than distal part; MP3 subdivided into three parts, distal part the shortest, the other two subequal. Labium. Median process of prementum rounded apically; LP1 and LP2 both subdivided into two parts, basal part about twice as long as distal part. Legs (Figs 19-20). Abdomen (Figs 23-24). Segment VII membranous ventrally; sclerite VII with an anterotransverse carina. Chaetotaxy. FR with about 115 slender, spine-like setae on anterior margin; mandible with a ring of multibranched setae on distal third.

\section{Megadytes (Trifurcitus) robustus (Aubé, 1838)}

Source of material. One specimen of instar III was used for the description. It was collected at the following locality: Villa Paranacito, Entre Rios Province, Argentina, 1983. Megadytes robustus is the only species of the subgenus Trifurcitus present in the area where the larva was collected.

Diagnosis. Larvae of $M$. robustus are characterized by the following combination of characters: medial projection of FR sharp apically, almost glabrous; lateral projections broad, flattened; mandible evenly curved, without ring of multi-branched setae; MP3 the shortest; median process of prementum slightly bilobed apically; abdominal segment VII sclerotized ventrally.

Instars I and II. No specimens were available for study.

Instar III. Colour. Head capsule reddish brown with numerous small, brown to dark brown maculae on the frontoclypeus (except the anterolateral corners) and all over the parietals (except the anterior third). Head appendages brown except for reddish brown mandible. Thoracic tergites pale yellow to yellow, with one longitu- dinal, brown band on each side of midline, and numerous dark brown maculae all over the surface. Abdominal tergites I to VI variegated, with pale yellow and brown longitudinal bands; sclerite VII pale yellow to light brown except for one lighter, longitudinal, dorsal band; sclerite VIII evenly light brown. Membranous parts white with light brown, longitudinal bands. Legs light brown, coxa with brown maculae. Urogomphus brown. Body. Measurements and ratios that characterize the body shape are shown in Table 1. Head capsule (Fig. 18). Subtriangular, about as long as broad; medial projection of FR sharp apically, almost glabrous; lateral projections broad, flattened. Mandible. Long, slender, evenly curved. Maxilla. MP3 the shortest; MP2 subdivided into two subequal parts; MP3 subdivided into three parts, distal part the longest, medial part the shortest. Labium. Median process of prementum slightly bilobed apically; LP1 subdivided into two parts, basal part longer than distal part. Legs (Figs 21-22). Abdomen (Figs 25-26). Segment VII sclerotized ventrally, ring-like, with an anterotransverse carina. Chaetotaxy. FR with 118 short, stout, apically rounded setae on anterior margin (except on medial projection); mandible without ring of multi-branched setae on distal third.

\section{Character analysis}

Thirty-two characters (25 binary and seven multistate, treated as unordered) were coded for third-instar larvae of nine species of Cybistrini and two outgroups (Table 2). In order to facilitate the interpretation of characters $02-05$, "medial projection" is the single projection of the frontoclypeus, which is placed in the middle of its anterior margin. "Lateral projections" are those that are at the sides of "medial projection". External to the "lateral projections" are the "lateral lobes" of the frontoclypeus, which were not considered in characters $02-05$. "Notch" between the "medial projection" and a "lateral projection" is the $\mathrm{V}$-shaped emargination present in that position. The characters used and their states are listed below:

00. Head capsule: (0) Subrectangular; (1) Subtriangular. 
01. Anterior margin of frontoclypeus: (0) Evenly rounded; (1) Deeply sinuate.

02. Medial projection of frontoclypeus: (0) Absent; (1) Sharp apically, with few subapical setae; (2) Truncate apically, with many apical setae directed forward.

03. Lateral projections of frontoclypeus: (0) Absent; (1) Broad, flattened, slightly projected forwards; (2) Not flattened, projected forwards.

04. Lateral projections of frontoclypeus: (0) Entire; (1) Bilobed; (2) Serrate; (3) Inapplicable.

05. Notches between medial and lateral projections of frontoclypeus: (0) Absent; (1) Wide to very wide; (2) Very narrow.

06. Setae on anterior margin of frontoclypeus: (0) Stout, rounded apically; (1) Slender, sharp apically.

07. Temporal, spine-like setae on parietal: (0) Present; (1) Absent.

08. Ventral, spine-like setae on parietal: (0) Present; (1) Absent.

09. Antennomere 1: (0) Not subdivided; (1) Subdivided into two parts.

10. Antennomeres 2 and 3: (0) Subdivided into two parts; (1) Subdivided into three parts.

11. Ratio antennomere 4/ antennomere 3: (0) Larger than 0.60 ; (1) Smaller than 0.20.

12. Mandible: (0) Evenly curved; (1) Distal third more strongly projected inwards.

13. Ring of long setae on distal third of mandible: (0) Absent; (1) Present.

14. Premaxillary lobes: (0) Not strongly developed; (1) Strongly developed, projected forward.

15. Maxillary stipes: (0) Short, subtrapezoidal; (1) Elongate, subcylindrical.

16. Galea: (0) Well developed, subconical; (1) Absent.

17. Maxillary palpifer: (0) Short; (1) Elongate, palpomere-like.

18. Maxillary palpomere 1: (0) Not subdivided; (1) Subdivided.

19. Maxillary palpomere 3: (0) Subdivided into two parts; (1) Subdivided into three parts.

20. Prementum: (0) Completely sclerotized; (1) Not sclerotized along a medial, sagittal, ventral band.

21. Median process of prementum: (0) Absent; (1) Not bilobed, rounded apically; (2) Slightly bilobed apically; (3) Deeply cleft, as two separate lobes.

22. Labial palpomere 1: (0) Not subdivided; (1) Subdivided.

23. Setae on median process of prementum: (0) Absent; (1) Present; (2) Inapplicable.

24. Ventral sclerites on prothorax: (0) Absent; (1) One; (2) Two.

25. Anteroventral row of setae on protibia: (0) Short, spiniform; (1) Elongate, natatory.

26. Row of natatory setae on posterodorsal surface of femur: (0) Absent; (1) Present.

27. Abdominal tergites I to VI: (0) Well developed; (1) Reduced.

28. Abdominal segment VII: (0) Membranous ventrally; (1) Sclerotized ventrally.

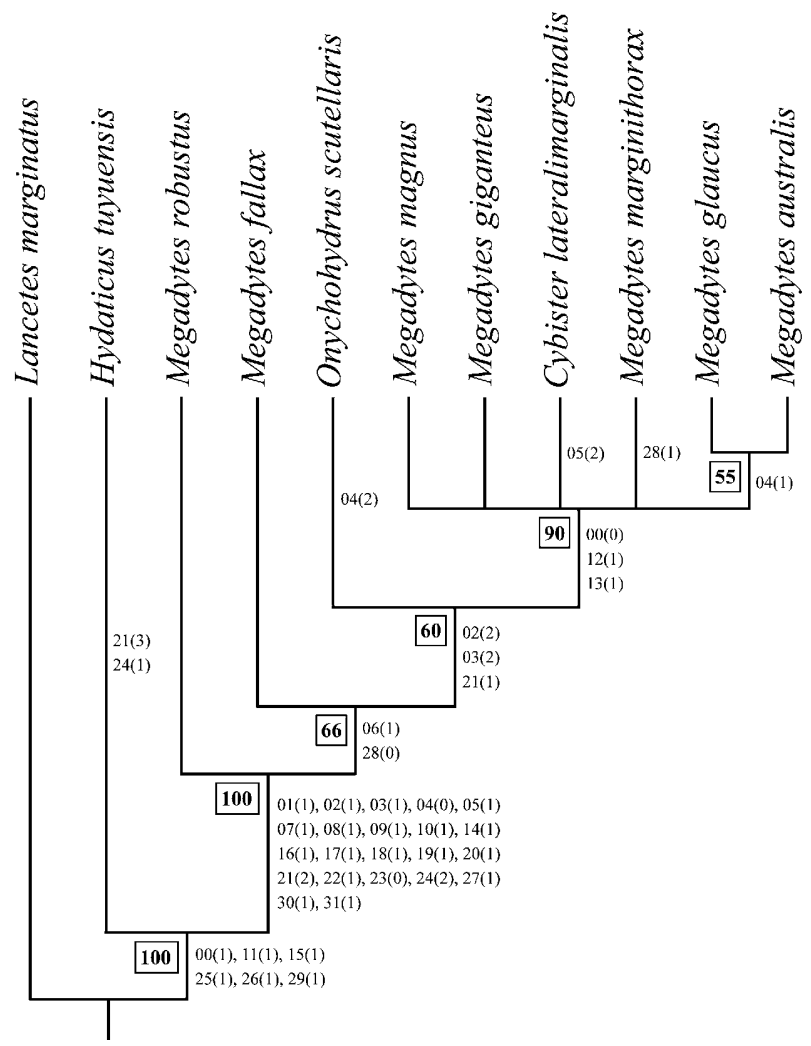

Fig. 27. Single parsimonious cladogram of 11 terminal taxa of larvae of Dytiscinae and Lancetinae, with character changes mapped for each clade. Jackknife values are indicated inside the boxes.

29. Abdominal segments VII and VIII: (0) Without lateral row of natatory setae; (1) With lateral row of natatory setae.

30. Abdominal segment VIII: (0) Completely sclerotized; (1) Completely sclerotized except ventrodistally around the anus.

31. Urogomphus: (0) Well developed; (1) Minute.

The analysis of the data matrix (Table 3 ) using the program TNT resulted in a single parsimonious cladogram of length $43, \mathrm{CI}=0.95, \mathrm{RI}=0.95$ (Fig. 27). Jackknife values indicate that the clades are well supported.

\section{DISCUSSION}

Chaetotaxy of members of Cybistrini has been little studied. An exception is the detailed treatment of the primary leg chaetotaxy of three species of Cybister by Nilsson (1988). In that paper, the chaetotaxy of Cybister is compared with the ancestral system of the Dytiscidae, and deviating features are discussed. Primary leg chaetotaxy of M. glaucus is very similar to that described for Cybister. As stated by Nilsson (1988), there are complex primary structures in the first-instar larva, and very little is added in the later instars. Also, the dense patch of slender spinulae on the protarsus of Cybister is present in $M$. glaucus along with the glandular head organs described by De Marzo \& Nilsson (1986). These head organs may act in association with the patch of spinulae of the protarsus as a device for spreading a secretion to 
inhibit microbial growth (De Marzo \& Nilsson, 1986). Another interesting chaetotaxic feature of M. glaucus is related to the presence of minute urogomphi. The study of the urogomphus of the first-instar larva indicates that they bear seven setae and one pore. This condition represents a reduction with respect to the common number of sensilla on dytiscid urogomphi (eight setae and three pores) (Alarie, 1995, 1998; Alarie et al., 2002), possibly related to the minute size of this structure in Cybistrini.

The phylogenetic study carried out here has considered only the data set provided by the third-instar larvae. The reason for this restriction is that the first two larval instars are unknown for most species (the exception is M. glau$c u s$, described in this paper). Also, this study has included a restricted number of species in relation to the whole diversity of the genus and the tribe Cybistrini. Therefore, the results of this cladistic analysis should be considered a preliminary study of the phylogenetic relationships of Megadytes, mainly done to evaluate the hypothesis of a monophyletic origin of this genus.

Previous papers on adult Dytiscidae (Miller, 2001) and Dytiscinae (Miller, 2000) provide strong evidence that the tribe Cybistrini is a natural group. This paper is not the proper context in which to test the monophyly of Cybistrini, because most tribes of Dytiscinae were not included in the analysis. However, several characters are distinctive for members of this tribe and therefore, the clade Cybistrini is strongly supported by larval characters (Jackknife value $=100)$. For this reason, it is worth mentioning the synapomorphies that support this clade, as they may serve as a basis for future, more comprehensive studies at the subfamily and tribe levels. Thirteen synapomorphies were discovered: (i) anterior margin of frontoclypeus deeply sinuate, with three projections (one medial and two lateral) separated by deep notches (characters 01-05); (ii) antennomeres 2 and 3 subdivided into three parts (character 10); (iii) premaxillary lobes strongly developed, projected forward (character 14); (iv) galea absent (character 16); (v) maxillary palpomere 3 subdivided into three parts (character 19); (vi) median process of prementum glabrous (character 23); (vii) abdominal tergites I to VI reduced (character 27); (viii) abdominal segment VIII completely sclerotized except ventrodistally around the anus (character 30); and (ix) urogomphus minute (character 31). Although other characters also appear as synapomorphies for Cybistrini, they should not be considered as such since they are present in other tribes of Dytiscinae. The absence of temporal and ventral spine-like setae on parietal (characters 07 and 08), a maxillary palpifer elongate, palpomere-like (character 17), a maxillary palpomere 1 subdivided (character 18) and a labial palpomere 1 subdivided (character 22) occur in Dytiscus harrisii Kirby, 1837 (Dytiscini) (M.C. Michat, pers. obs.). Antennomere 1 subdivided into two parts (character 09) is found in D. harrisii, Hyderodes shuckardi Hope, 1838 (Hyderodini) and Eretes australis (Erichson, 1842) (Eretini) (Watts, 1964; Miller, 2002; M.C. Michat, pers. obs.). A median process of the prementum either rounded apically (not bilobed) or slightly bilobed apically (character 21) is present in E. australis and Thermonectus succinctus (Aubé, 1838) (Aciliini), respectively (Miller, 2002; Michat \& Torres, 2005). Two ventral sclerites on the prothorax (character 24) are found in H. shuckardi (Watts, 1964). A prementum not sclerotized along a medial, sagittal, ventral band (character 20) distinguishes Cybistrini from the other subfamilies of Dytiscinae. However, I have observed a similar state in several species of Rhantus Dejean, 1833 (s. lat.) (Colymbetini).

The cladistic analysis presented here has implications for the phylogeny of the genus Megadytes. The species Cybister lateralimarginalis (De Geer, 1774) and Onychohydrus scutellaris (Germar, 1848) were included mainly to test the monophyly of Megadytes, and the result shows that both species are nested inside this genus. Members of the subgenus Trifurcitus are strange elements within Megadytes, since the remaining species of Cybistrini studied share three synapomorphies (Jackknife value $=$ 60): (i) medial projection of frontoclypeus truncate apically, with many apical setae directed forwards (character 02); (ii) lateral projections of frontoclypeus projected forwards, not flattened (character 03); and (iii) median process of prementum rounded apically, not bilobed (character 21). It must be mentioned, however, that in some specimens of $M$. fallax the median process of the prementum is not clearly bilobed but rounded apically. These results contradict those obtained by Miller et al. (in press), which support the monophyly of Megadytes.

Based on the data set analysed here, the subgenus Trifurcitus is resolved as non-monophyletic. This is because M. fallax shares with the remaining species of Cybistrini studied (except $M$. robustus) two synapomorphies (Jackknife value $=66$ ): (i) setae on anterior margin of frontoclypeus slender, sharp apically (character 06); and (ii) abdominal segment VII membranous ventrally (character 28). Megadytes robustus has stout, apically rounded setae on the anterior margin of frontoclypeus, and abdominal segment VII is sclerotized ventrally; both characters are viewed as plesiomorphic within Cybistrini and are present in the outgroups. Both species of Trifurcitus share a subtriangular head and evenly curved mandibles, which lack a ring of long, hair-like setae on the distal third. These characters are plesiomorphic within Cybistrini.

The clade composed of the remaining three subgenera of Megadytes and C. lateralimarginalis is well supported (Jackknife value $=90$ ). Members of this clade share three synapomorphies: (i) head capsule subrectangular (character 00); (ii) distal third of mandible more strongly projected inwards (character 12); and (iii) presence of a ring of long, hair-like setae on distal third of mandible (character 13). However, this study failed to improve the resolution within this clade, and therefore the taxa form a polytomy. The two species of the subgenus Paramegadytes form a distinct but not highly supported clade (Jackknife value $=55$ ), as they both have bilobed lateral projections on the frontoclypeus (character 04). According to Crespo (1982), both species of Paramegadytes can be distinguished by the relative head width. 
Megadytes (M.) marginithorax is characterized by very narrow notches between the medial and lateral projections of the frontoclypeus (character 05). No synapomorphies were discovered to group the two species of the subgenus Bifurcitus. The presence of a fully sclerotized abdominal segment VII in M. giganteus (Ferreira-Jr., 1993) needs corroboration, because in the closely related species, $M$. magnus, abdominal segment VII is membranous ventrally.

The analysis presented here should be considered as a preliminary study of the phylogenetic relationships of members of Megadytes within the Cybistrini, based on larval characters. Further research including other data sets, as that provided by first-instar larval chaetotaxy, is needed. Larval morphology and chaetotaxy within the tribe are still poorly known. Larvae of the small genera Austrodytes Watts, 1978, Regimbartina Chatanay, 1911 and Spencerhydrus Sharp, 1882, as well as of most species of Cybister, Megadytes and Onychohydrus are unknown, and nearly all descriptions do not include sufficient detail of the morphometry and chaetotaxy. Future studies should focus on providing good descriptions of larvae of this tribe, which will improve the resolution of future analyses of the phylogeny of Cybistrini.

ACKNOWLEDGEMENTS. I am deeply grateful to A.O. Bachmann, P.L.M. Torres and two anonymous referees for their critical review of the manuscript and valuable suggestions and comments. Thanks also to P.L.M. Torres and S. Mahl for donation of larval material. My field and laboratory work was supported by a postgraduate scholarship and grant PIP 02541/00 from the Consejo Nacional de Investigaciones Científicas y Técnicas de la República Argentina (CONICET).

\section{REFERENCES}

Alarie Y. 1995: Primary setae and pores on the legs, the last abdominal segment, and the urogomphi of larvae of Nearctic Colymbetinae (Coleoptera: Adephaga: Dytiscidae) with an analysis of their phylogenetic relationships. Can. Entomol. 127: 913-943.

AlARIE Y. 1998: Phylogenetic relationships of Nearctic Colymbetinae (Coleoptera: Adephaga: Dytiscidae) based on chaetotaxic and porotaxic analysis of head capsule and appendages of larvae. Can. Entomol. 130: 803-824.

Alarie Y., Archangelsky M., Nilsson A.N. \& Watts C.H.S. 2002: Larval morphology of the genus Lancetes (Coleoptera: Adephaga: Dytiscidae): the hypothesis of sister-group relationship with the subfamily Dytiscinae revisited. Can. Entomol. 134: 467-501.

Bertrand H. 1934: Notes sur quelques larves de coléoptères aquatiques. Ann. Soc. Entomol. Fr. 103: 363-382.

Cekalovic Kuschevich T. 1974: Descripción de la larva de Megadytes australis (Germain), 1854 (Coleoptera, Dytiscidae). Bol. Soc. Biol. Concep. 48: 33-40.

Crespo F.A. 1982: Megadytes (Paramegadytes) glaucus (Brullé), descripción del tercer estadio larval y de la pupa (Dytiscidae, Coleoptera). Physis (B) 41: 7-13.

De Marzo L. 1979: Studi sulle larve dei coleotteri ditiscidi. X. Anatomia e funzionamento dell'aparato succhinate cibario- faringeo in alcune forme larvali delle subff. Dytiscinae, Colymbetinae, Laccophilinae e Hydroporinae. Entomologica (Bari) 15: 5-72.

De Marzo L. \& Nilsson A.N. 1986: Morphological variation and fine structure of some head structures in larvae of Dytiscidae (Coleoptera). Entomol. Basil. 11: 29-42.

FERREIRA JR. N. 1993: Descricáo da larva de Megadytes giganteus (Castelnau, 1834) com notas biológicas (Coleoptera: Dytiscidae). Revta. Bras. Entomol. 37(1): 57-60.

FERREIRA JR. N. 1995: Description of the larvae of Megadytes fallax (Aubé) and M. marginithorax (Perty) (Coleoptera: Dytiscidae). Coleopt. Bull. 49: 313-318.

FIORI G. 1949: Contributi alla conoscenza morfologica ed etologica dei coleotteri III. Le larve dell'Acilius sulcatus L. e del Cybister lateralimarginalis De Geer (Dytiscidae). Boll. Ist. Entomol. Univ. Bologna 17: 234-264.

Goloboff P., FARris J. \& Nixon K. 2003: T.N.T.: Tree analysis using new technology. Program and documentation, available from the authors, and at http://www.zmuc.dk/public/phylogeny.

LAWRENCE J.F. 1991: Order Coleoptera. In Stehr F.W. (ed.): Immature Insects. Vol. 2. Kendall/Hunt, Iowa, pp. 144-658.

Michat M.C. \& Torres P.L.M. 2005: Larval morphology of Thermonectus succinctus (Aubé 1838) (Coleoptera: Dytiscidae: Dytiscinae), with biological notes and chaetotaxic analysis. Aquat. Insects 27: 281-292.

Michat M.C. \& Torres P.L.M. 2006: Hydaticus tuyuensis Trémouilles (Coleoptera: Dytiscidae): larval morphology and phylogenetic relationships within Dytiscinae. Hydrobiologia 563: 479-492.

Michat M.C., Archangelsky M. \& Torres P.L.M. 2005: Descriptions of the preimaginal stages of Lancetes marginatus (Steinheil) and L. biremis Ŕíha (Coleoptera: Dytiscidae), and comparative notes with other Lancetes larvae. Stud. Neotr. Faun. Env. 40: 129-142.

Miller K.B. 2000: Cladistic analysis of the tribes of Dytiscinae and the phylogenetic position of the genus Notaticus Zimmermann (Coleoptera: Dytiscidae). Insect Syst. Evol. 31: 165-177.

MiLLER K.B. 2001: On the phylogeny of the Dytiscidae (Insecta: Coleoptera) with emphasis on the morphology of the female reproductive system. Insect Syst. Evol. 32: 45-92.

MilLER K.B. 2002: Revision of the genus Eretes Laporte, 1833 (Coleoptera: Dytiscidae). Aquat. Insects 24: 247-272.

Miller K.B., Bergsten J. \& Whiting M. (in press): Phylogeny and classification of diving beetles in the tribe Cybistrini (Coleoptera, Dytiscidae, Dytiscinae). Zool. Scripta.

NiLSson A.N. 1988: A review of primary setae and pores on legs of larval Dytiscidae (Coleoptera). Can. J. Zool. 66: 2283-2294.

Nilsson A.N. 2001: World Catalogue of Insects. Vol. 3. Dytiscidae (Coleoptera). Apollo Books, Steenstrup, Denmark, $395 \mathrm{pp}$.

Trémouilles E.R. \& Bachmann A.O. 1980: La tribu Cybisterini en la Argentina (Coleoptera, Dytiscidae). Rev. Soc. Entomol. Arg. 39(1-2): 101-125.

WatTs C.H.S. 1964: The larvae of Australian Cybister spp. Curt., Homeodytes spp. Reg. and Hyderodes shuckardi Hope (Coleoptera: Dytiscidae). Trans. R. Soc. S. Aust. 88: 145-156.

Received December 23, 2005; revised and accepted June 2, 2006 